$11-29-2011$

\title{
Response to House Memorial 41 Requesting a Study of the Use of Natural Gas as a Transportation Fuel
}

\author{
Kevin Washburn \\ University of New Mexico - School of Law \\ Kevin Boberg \\ New Mexico State University - Arrrowhead Center \\ Jeffrey Kendall \\ University of New Mexico - School of Law
}

Follow this and additional works at: https://digitalrepository.unm.edu/law_facultyscholarship

Part of the Indian and Aboriginal Law Commons

\section{Recommended Citation}

Kevin Washburn, Kevin Boberg \& Jeffrey Kendall, Response to House Memorial 41 Requesting a Study of the Use of Natural Gas as a Transportation Fuel, (2011).

Available at: https://digitalrepository.unm.edu/law_facultyscholarship/528

This Court Filing is brought to you for free and open access by the UNM School of Law at UNM Digital Repository. It has been accepted for inclusion in Faculty Scholarship by an authorized administrator of UNM Digital Repository. For more information, please contact amywinter@unm.edu, Isloane@salud.unm.edu,

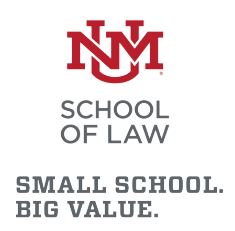

BIG VALUE. 


\section{RESPONSE TO HOUSE MEMORIAL 41REQUESTING A STUDY OF THE USE OF NATURAL GAS AS A TRANSPORTATION FUEL}

\section{Overview \\ Legal and Infrastructure Issues}

Kevin Washburn, Dean and Professor of Law University of New Mexico School of Law Jeffrey M. Kendal, Dean's Research Fellow at the University of New Mexico School of Law Kevin B. Boberg, CEO Arrowhead Center at New Mexico State University

$11 / 28 / 2011$

This paper is drafted in response to The State of New Mexico, 50th Legislature, 1st Session House Memorial 41, Requesting a Study of the Use of Natural Gas as a Transportation Fuel. The task of the University of New Mexico Law School was to examine and report on potential liability and litigation issues associated with the use of natural gas as a transportation fuel. The task of the Arrowhead Center at New Mexico State University was to examine and report on infrastructure issues related to the use of natural gas as a transportation fuel. 


\section{Contents}

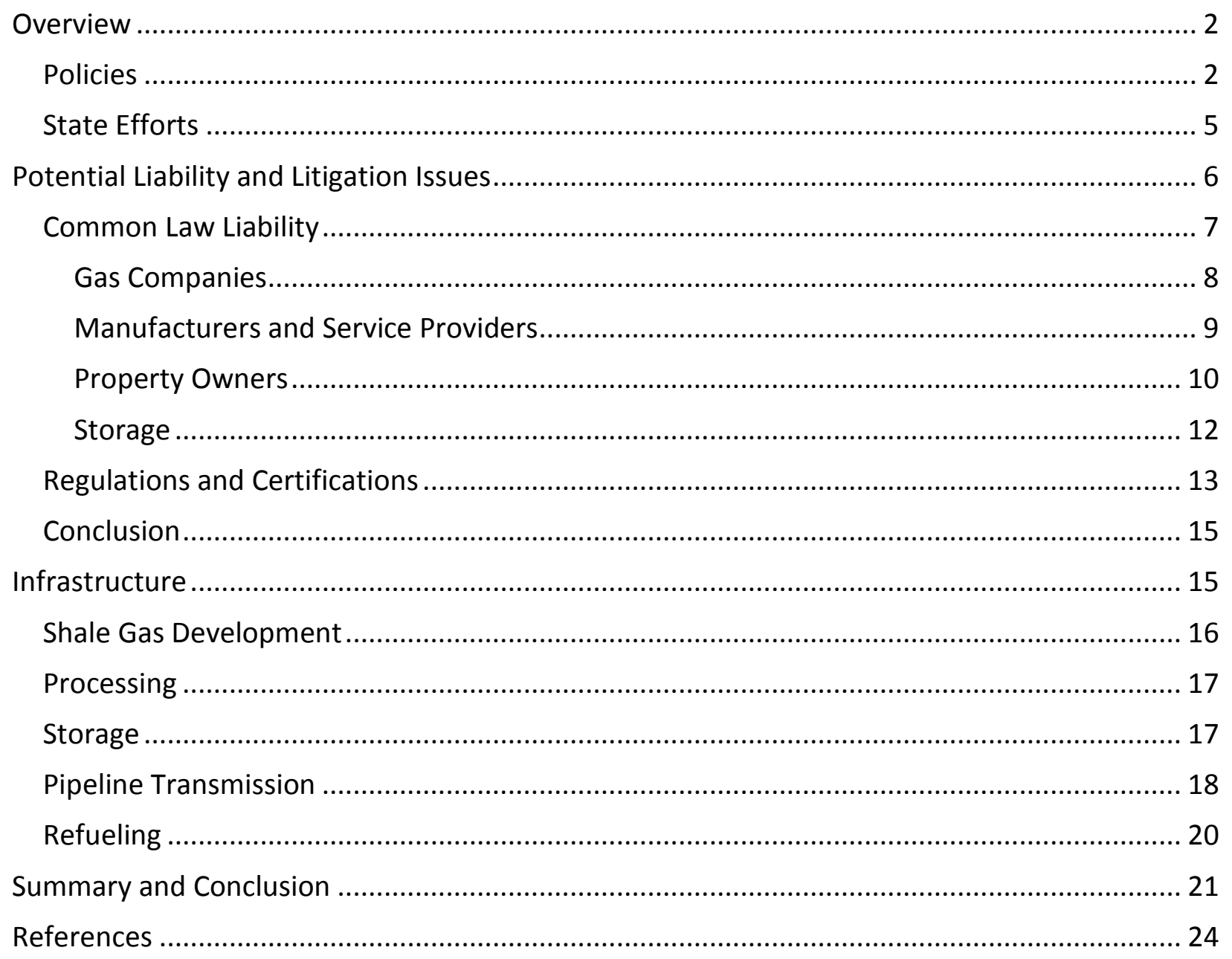




\section{Overview}

In 2010, MIT released its exemplary report The Future of Natural Gas: An

Interdisciplinary MIT Study (Connors et al. [MIT]). The executive summary of this report places natural gas "at the center of the current debate on energy, security, and climate," as well as a potential "bridge to a low-carbon future" between higher-emissions fossil fuels and renewable energy sources (Connors et al. [MIT] xi). Given its domestic abundance (particularly in "unconventional" resources such a shale), relatively low contribution to greenhouse gases, technological advances in production and processing, and the likelihood of stricter carbon constraint legislation, natural gas is poised to play a greater role in U.S. energy through midcentury (Connors et al. [MIT], xi, xii). Further, natural gas tends to be less costly than petroleum-based fuels on an "energy equivalent basis" (although changeable market factors affect this [e.g., Kragha 11]) and can help decrease U.S. dependence on foreign sources of fuel (Werpy et al. 8). While these advantages are considerable, there are questions to be answered and challenges to be addressed. As the possibility of wide-spread production, distribution, and consumption arises, so too does potential legal issues. Operationally, the counterbalance in the natural gas industry is its infrastructure, which presents pressing challenges to the widespread adoption of natural gas as a transportation fuel. The New Mexico Legislature's resolution that "Increased use of natural gas as a transportation fuel would be beneficial to New Mexico and the U.S." is timely and compelling.

\section{Policies}

Any deliberations on increased adoption of natural gas must take into account likely scenarios emerging from federal climate and energy policy. While natural gas has lower carbon 
emissions than other fossil fuels, potential legislation creates an air of uncertainty regarding its share in overall energy - some situations pose possibilities for significant increases, others create constraints (Connors et al. [MIT], xiii). An overview of energy and fuel regulations from the 1980 s to present demonstrates the effects of legislation on this industry.

In 1988, the Alternative Motor Fuels Act initiated vehicle manufacturer Corporate Average Fuel Economy (CAFE; a program that measures a fleet's average fuel economy) credits, offsetting deficiencies in this area in return for research on and production of alternative fuel vehicles. The 1990s saw two important legislative developments affecting the natural gas industry. The Clean Air Act Amendments of 1990, a set of revisions to the original Act adopted in 1970, established increased regulatory authority for the EPA and introduced a number of plans affecting vehicle emissions and fuel composition and quality (http://www.afdc.energy.gov/afdc/laws/key legislation\#caaa90). Two provisions specifically cited natural gas: promotion of clean, low sulfur coal and natural gas and stimulation of grain and natural gas markets to decrease dependence on imported oil by 1,000,000 barrels per day (http://epa.gov/oar/caa/caaa_overview.html). This encouraged development of "clean alternative fuel," sparking greater renewed interest in natural gas as a transportation fuel (Kragha 28). The second major initiative in this area in the 1990s was the Energy Policy Act of 1992, which, in an attempt to increase energy security, sought grant programs and research for alternative fuels vehicles, while outlining tax incentives for these vehicles. The Energy Policy also took the specific step of increasing the presence of alternative fuels vehicles in government fleets (Kragha 29), as well as launching the Clean Cities program, which aims to "advance the 
nation's economic, environmental, and energy security by supporting local actions to reduce petroleum consumption in transportation" (http://www1.eere.energy.gov/cleancities/).

Energy and fuel legislation has continued to evolve in the $21^{\text {st }}$ century. The Energy Independence and Security Act of 2007 stipulated that all federal fleet purchases be "low greenhouse gas emitting" (Kragha 30;

http://www1.eere.energy.gov/femp/regulations/eisa.html), continued CAFE credit programs created in previous legislation to 2027, and allowed tax credits for natural gas production and vehicles (Kragha 30). The American Recovery and Reinvestment Act of 2009 contained approximately $\$ 300,000,000$ of competitive grants for alternative fuel vehicle initiatives, as well as enhanced infrastructure tax credits for alternative fuel equipment (http://www.afdc.energy.gov/afdc/laws/arra). Finally, the Tax Relief, Unemployment Insurance Reauthorization, and Job Creation Act of 2010 extended those incentives through 2011 (http://www.ngvc.org/incentives/federalTax.html).

As these policies indicate, merely encouraging research and development of alternative fuel technologies is not sufficient to affect meaningful changes in adoption of these technologies. Infrastructure issues figure large in these situation, as increasing inclusion of incentives demonstrate. For instance, while the Alternative Motor Fuels Act garnered positive responses from manufacturers and led to a considerable increase in vehicle availability, insufficient infrastructure, particularly in refueling sites, limited the impact of the program (http://www.nhtsa.gov/cars/rules/rulings/CAFE/alternativefuels/exec-summary.htm). 


\section{State Efforts}

Many states have instituted programs to incentivize the use of alternative fuels, including natural gas. Arizona, for instance, allows alternative fuel vehicles to travel in high occupancy vehicle lanes and provides parking incentives, reduced license/registration taxes, and fuel use tax exemptions

(http://www.afdc.energy.gov/afdc/progs/ind state laws.php/AZ/NG). Colorado provides income tax credits, sales tax exemptions, and weight limit exemptions for alternative fuel vehicles (http://www.afdc.energy.gov/afdc/progs/ind state laws.php/CO/NG). New Mexico offers alternative fuel vehicle and fueling infrastructure grants and an alternative fuel tax exemption (http://www.afdc.energy.gov/afdc/laws/laws/NM/tech/3253). Of the southwestern states, Utah has orchestrated one of the most comprehensive efforts to increase use of natural gas in transportation.

In 1981, the State of Utah, in cooperation with Questar Gas (a natural gas distributor), initiated a program to increase use of natural gas through the conversion of 25 fleet vehicles from petroleum-fueled systems and the construction of a fueling compression station. By 1989, a second station was completed, followed by others conceived in response to the National Energy Policy of 1992 and associated increases in OEM production of NGVs and the presence of natural gas conversion shops. The program has continued, sparked recently by resurgence in interest in NGV in reaction to historically high petroleum prices. Accordingly, Utah's NGV capacity increased by $45 \%$ between 2009 and 2010, with no end in sight for expansion of the industry (Jibson, 22). 
Despite its demonstrable success in increasing use of natural gas as a transportation fuel, Utah is burdened by the most common infrastructure challenge in the sector - a lack of fueling facilities, particularly those that can accommodate public access. While ideas for addressing this problem (e.g., coordinating with fleet fueling facilities to allow public use and leasing space in existing, conventional fueling stations) have been advanced, none have offered adequate incentives to significantly increase consumer adoption of natural gas vehicles - Jibson notes that despite estimates by the American Gas Association in the 1990 s that $12,000,000$ natural gas vehicles would be in use in the U.S. by 2010 , the actual number was closer to 120,000 (25). Despite the concerted efforts of the State of Utah, its program is stymied by natural gas infrastructure deficits.

\section{Potential Liability and Litigation Issues}

Many liability and litigation issues associated with a compressed natural gas vehicle (CNG/V) infrastructure mirror those of a traditional gasoline vehicle infrastructure. The tort system in the United States can adequately handle many of the issues that would arise in relation to CNG or CNGVs through negligence and strict products liability causes of action. Also, similar combustible gases, like propane, and the issues that arise in relation to the transmission, storage, and distribution of such gases, help to illuminate CNG liability concerns. Case law involving similar combustible gases can be analogized to more fully understand the potential liability and litigation issues associated with CNG as a transportation fuel. An increased CNGV infrastructure does not create new legal theories of liability, but instead will create new factual scenarios giving rise to liabilities. Further, New Mexico has adopted comprehensive standards 
for CNGVs in the form of the Vehicular Gaseous Fuel Systems Code, NFPA 52. Therefore, New Mexico has sufficient means to handle liability issues that arise in an increased CNGV infrastructure based on established state and federal standards for CNGVs and the common law tort system.

\section{Common Law Liability}

The distribution of CNG in a CNGV infrastructure dictates the major liabilities that will arise in a CNGV infrastructure. CNG can be distributed in 2 ways: (1) centralized or fleet only; and (2) decentralized or dispersed. A centralized CNG infrastructure creates less liability issues than a dispersed distribution infrastructure because there are less fill stations that can be maintained and monitored more closely. With dispersed distribution, operating fill stations in multiple locations throughout a city or region, or even installing fill stations in individuals' homes, potential liabilities increase. In addition, the more fill stations in a region, the more public safety concerns will increase due to public uncertainty about CNG technology. ${ }^{1}$ Liability issues often involve public safety concerns. For CNG, the safety concerns are no different than those for gasoline vehicles. ${ }^{2}$

In particular, a CNGV infrastructure that allows self-fill stations to be installed in homes creates unique liabilities. Liabilities stem from the installation, maintenance and care of home fill stations. Particular facts of a given case determine fault when a CNG storage device leaks or

\footnotetext{
${ }^{1}$ Joshua P. Fershee, Struggling Past Oil: The Infrastructure Impediments to Adopting NextGeneration Transportation Fuel Sources, 40 Cumb. L. Rev. 87, 88, 108-9 (2010) (discussing the public's CNG safety misperceptions and internalizing risks).

${ }^{2}$ Id. (clarifying CNG tanks are thicker than gasoline and are put through rigorous testing, and $\mathrm{CNG}$ is light and will dissipate instead of pool when there is a leak).
} 
explodes. The liable party can be the owner, the gas company, the manufacturer, or even the maintenance contractor depending on the facts and circumstances.

\section{Gas Companies}

Basic negligence elements: duty, breach, causation and damages, will determine the liability of a gas company in the case of an injury sustained on a customer's property as a result of a gas explosion. In Adams v. Northern Illinois Gas Co., a gas company sought summary judgment after an individual was killed in a natural gas explosion because they did not install, own, or control the pipes or fixtures on the customer's premises. 211 III. 2 d 32, 809 N.E.2d 1248 (2004). The gas company did not have a duty to maintain the condition of the pipes absent knowledge of a leak on the customer's premises. The court held that summary judgment for the gas company was improper because the gas company had actual knowledge that connectors were corroded and, therefore, the gas company had a duty to warn the plaintiff of the danger.

In Hopkins v. Mississippi Valley Gas Co., a natural gas company escaped liability when a fire started by the water heater pilot light destroyed a home and killed the plaintiff's grandson. 2002-CA-01185-COA (Miss. Ct. App. 2004). The court held the natural gas company did not breach their duty to use the highest degree of care when supplying natural gas to the homeowner because the gas company had warned the homeowner several times about the dangers of storing flammable items near a water heater and had removed gasoline stored near the tank prior. 
Though both cases involve natural gas supplied to a home, the same negligence analysis would apply to a centralized CNG station used by private consumers in a traditional gas station like setting or for a CNG station servicing fleet vehicles.

\section{Manufacturers and Service Providers}

Manufacturers and service providers in a CNGV infrastructure may also face liabilities in tort. In Duncan v. M \& M Auto Service, Inc., a CNGV owner, who sustained injuries when an explosion occurred while refueling his CNGV, brought negligent installation and maintenance of a CNG system, and strict product liability actions versus the automobile shop that converted his van to run on CNG. 898 N.E.2d 338 (Ind. Ct. App. 2008). The case involved issues with the "check valve," which serves to restrict gas from escaping back through the receptacle during refueling. The Indiana Court of Appeals held that the shop was not subject to strict products liability as an apparent manufacturer, was not negligent in installation and did not have a duty to maintain the van. The court noted, the auto shop was a certified installer of the particular CNG system, and at least one of the employees had attended a multi-day training session on CNG systems.

In some cases, strict liability may be asserted against parties, including manufacturers, when their activities are ultrahazardous or abnormally dangerous. In New Mexico, the case of Apodaca v. AAA Gas Co., involved a propane explosion that injured two repairmen and killed another. 2003-NMCA-085, 134 N.M. 77, 73 P.3d 215. The injured parties brought suit alleging the propane distributor and manufacturer were negligent, or strictly liable, for providing a defective valve, which they misrepresented as new and unused. The plaintiffs also brought suit versus the propane seller for failing to remove the propane from the truck before delivering it 
for repair, violating the city fire code, and creating an ultrahazardous condition. The plaintiffs characterized the ultrahazardous activity as the delivery of a truck loaded with propane for repairs to those not expert and trained in handling such gas (the repair shop was located in the heart of Albuquerque). The New Mexico Court of Appeals upheld the jury's decision finding for the defendants. The court deemed the cause of the explosion was carelessness, and said repairing a propane truck was not an ultrahazardous activity warranting strict liability. But see Thigpen v. Skousen \& Hise, 64 N.M. 290, 294, 327 P.2d 802, 805 (1958) (finding dynamite blasting ultrahazardous because high explosives used and level of uncertainty involved). It is not uncommon in the industry for a propane truck to be delivered for repair with propane still in the tank.

\section{Property Owners}

Depending on the particular facts and circumstances, a property owner may be found liable for an injury sustained in relation to a gas explosion. In Searle v. Suburban Propane Div. of Quantum Chem. Corp., a homeowner was fatally injured in a propane explosion that occurred at his home. 263 A.D.2d 335, 700 N.Y.S.2d 588, 591 (N.Y. App. Div. 2000). The propane supply and distribution system that exploded was custom fabricated and installed by the defendants who ran piping from the outdoor storage tank, underneath a deck, and into the basement of the home. The explosion was caused when the decedent had shoveled snow off the roof onto the wood deck, causing it to collapse and rupture the underlying pipeline, creating the leak that lead to the explosion. The plaintiffs brought action to recover for decedent's wrongful death and conscious pain and suffering, plaintiff's emotional distress and loss of consortium, and property damage. The alleged causes of action sounded in ordinary 
negligence and res ipsa loquitur, strict liability based upon the ultrahazardous nature of the activity, products liability based upon defective design and mistake in the manufacturing process, and breach of implied warranty. The New York Appellate Division held that: a prima facie showing of the defendant's negligence as found by the lower court raised material questions of fact related to the breach of warranty and defective design causes of action; the installation and maintenance of a propane gas storage tank did not constitute an ultrahazardous activity so as to impose absolute liability since reasonable precautions could have been taken to prevent explosion; it was proper to dismiss the negligence cause of action based on res ipsa loquitor because the propane transmission system installed at decedent and plaintiff's home was not within defendant's exclusive control; and the defective manufacturing cause of action was properly dismissed because there was no evidence of defective design.

In Jaramillo v. Fisher Controls Co., Inc., the New Mexico Court of Appeals faced a litany of evidence, jury instruction, and duty issues when the plaintiffs brought product liability and negligence actions against the seller and manufacturer of a gas regulator, and against the company that filled the propane tank that attached to the regulator after it exploded. 102 N.M. 614, 698 P.2d 887 (Ct. App. 1985). Among the holdings, the court recognized Scott v. Rizzo, 96 N.M. 682, 634 P.2d 1234 (1981), and said that when apportioning fault in a products liability action the plaintiffs have a duty to exercise ordinary care for their own safety and the safety of their property. In the installation of a CNG station, where an injury results therefrom, the apportionment of fault between the installer manufacturer and owner must be determined based on the particular facts and circumstances. The court found that adopted standards 
(discussed infra) imposed a duty of compliance on the plaintiff who purchased the propane regulator to test the home stove, which they breached.

\section{Storage}

In both a centralized and decentralized CNG distribution infrastructure, the storage of CNG presents liability issues. The threat of a leak is always present, and fault for an injury resulting from a leak will depend on the particular circumstances. In Stadish v. Southern California Gas Co., a gas company faced a toxic tort action brought by a resident of a home located near an underground natural gas storage facility who developed various health issues, which she alleged were the result of exposure to toxic substances. 2002 WL 1360667 (Cal. App. 2d Dist. 2002) (California Rules of Court, Rule 8.1115, restricts citation of unpublished opinions in California courts). The plaintiff alleged toxic torts including negligence, public nuisance, assault and battery, and intentional infliction of emotional distress, but failed to prove there was an actual leak that affected the resident while in the home. On appeal, the Los Angeles County Superior Court held that the resident was not exposed to toxic substances from the facility in an amount sufficient to cause injury, and the plaintiffs failed to prove the causation element of the tort action.

Stadish was decided based on very sophisticated medical expert testimony and technical scientific gas storage determinations. The CNG was stored in naturally occurring geologic formations that contained remnants of crude oil, and the interaction created increased levels of Benzene. The natural gas would escape from the facility through leaks and during repairs and maintenance. Such storage of CNG, even though this case deals with storage in underground formations present with crude oil, indicates the types of complex liability issues that can arise in 
an increased CNG infrastructure. The determination of liability when causes of action are brought for injuries sustained in relation to CNG or CNGVs will depend on the particular facts and circumstances surrounding each case.

\section{Regulations and Certifications}

In an increasing CNGV infrastructure, state certifications and regulations play a prominent role in future liabilities. It is recognized in New Mexico that, "[I]egislatively authorized rules and regulations have the force of law," and the "[v]iolation of a properly adopted and filed rule or regulation is negligence per se." Jaramillo v. Fisher Controls Co., 102 N.M. 614, 619, 698 P.2d 887, 892 (Ct. App. 1985). CNGVs are not a new technology. They have been used extensively in other countries since the 1940s, and were adopted in the United States in the late 1970s. ${ }^{3}$ The growth of the CNGVs in the United States prompted the adoption of national standards. Therefore, many state and federal regulations already exist and can guide a state like New Mexico in the technical aspects of an increased CNG and CNGVs infrastructure.

Major regulations include: NFPA 52, Vehicular Gaseous Fuel Systems Code (National Fire Protection Association 2010); 49 C.F.R. $§ 571.304$ (2010) - DOT CNG Fuel Container Integrity Safety Standards; New Mexico Liquefied Petroleum Gas Standard, 19.15.40 NMAC (2/1/2006) and other state administrative regulations; State Liquefied Petroleum Gas and Compressed Natural Gas Act (CNG Act), NMSA 1978, Sections 70-5-1 to -23 (1947, as amended through

\footnotetext{
${ }^{3}$ NFPA 52, Vehicular Gaseous Fuel Systems Code, Origin and Development (National Fire Protection Association 2010) (also covers Liquefied Natural Gas, compressed hydrogen, and liquefied compressed hydrogen).
} 
1999) and other state statutes; and the Albuquerque Fire Code, $\S 14-2-1(B)(3)(1993)$, and other city codes.

In New Mexico, NFPA 52 standards have been adopted through the CNG Act, NMSA 1978, Section 70-5-5 (1947, as amended through 1993), the NMAC Liquefied Petroleum Gas Standard, 19.15.40.24(F) NMAC, and through city ordinances like the Albuquerque Fire Code, Section $1(B)(2)$. The NFPA 52 is a fully comprehensive, twenty one chapter, code covering everything from CNG equipment requirements and residential fueling facilities to CNG compression and fire protections. The adoption of CNGV standards by the state legislature in the CNG Act, the Construction Industries Division in the administrative code, and the City of Albuquerque in their fire code, firmly establishes the NFPA 52 guidelines and standards in New Mexico. Should the state of New Mexico's CNG infrastructure mature and grow in the coming years, sufficient standards and regulations have been adopted to guide participants and to enforce safety standards.

Another concern when considering alternative fuel usage is the Environmental Protection Agency (EPA), who is responsible for ensuring that all vehicles and engines sold in the United States, including aftermarket conversions, meet emission standards. The legal concerns related to CNGVs and an increased CNG infrastructure stem from the Clean Air Act's section 203(a)(3) prohibition against tampering (42 U.S.C. $§ 7522$ (a)(3)). Recently, the EPA issued a conversion friendly final rule ${ }^{4}$ that "creates additional compliance options beyond certification that protect manufacturers of clean alternative fuel conversion systems against a tampering violation, depending on the age of the vehicle or engine to be converted." The EPA

\footnotetext{
${ }^{4}$ Clean Alternative Fuel Vehicle and Engine Conversions, 76 Fed. Reg. 19,830 (April 8, 2011) (to be codified at 40 C.F.R. pts. 85 and 86).
} 
hopes the new options for manufacturers will help to "alleviate some economic and procedural impediments to clean alternative fuel conversions while maintaining environmental safeguards to ensure that acceptable emission levels from converted vehicles are sustained."

The statutory tampering prohibition is important because of the threat of increased emissions caused by poorly designed and installed modifications. However, the new EPA tampering exemption protocols allow manufacturers to demonstrate that emission controls in the converted vehicle or engine will continue to function properly and that pollution will not increase as a result of conversion.

\section{Conclusion}

New Mexico has sufficient legal safeguards for an increased CNG and CNGV infrastructure. The common law tort system can handle any causes of action resulting in injury that arise in relation to the storage, transportation, manufacture, or usage of CNG or CNGVs. In a developing and growing CNGV infrastructure, New Mexico has adopted and will be guided by the comprehensive NFPA 52 guidelines for CNG engine fuel systems, dispensing systems, and storage. So, liability and litigation issues related to CNG as a transportation fuel are not new, and they should not be a major concern when considering growing the CNGV infrastructure in New Mexico.

\section{Infrastructure}

Demand for natural gas in the U.S. is generally relegated to three primary sectors: power, heating, and industry, with the electricity sector cited as the areas with the greatest potential for growth, given current and pending CO2 emission regulation (Connors et al. [MIT], xiv). The use of natural gas to replace coal in power generation may be a near-term carbon 
emissions solution as development of renewable sources advances, but natural gas is expected to be displaced by the same sort of emissions restrictions that might increase its use in the near future (Connors et al. [MIT], xiv). While natural gas is produced throughout North America (and, as noted, new means of accessing unconventional sources are increasing capacity), production frequently occurs at a great distance from end consumers, requiring a robust infrastructure of storage and transmission, in addition to processing and delivery. A succinct summary of the natural gas infrastructure situation may be found in an ICF International (a professional services and technology firm with government and commercial clients) report delivered to the Interstate Natural Gas Association of America a report of storage and pipeline infrastructure projections through 2030:

A growing natural gas market generally requires additional natural gas infrastructure. Even in a flat or declining market, however, additional natural gas pipeline and storage assets will be necessary if there are shifts in the location of supply and demand (9).

Without significant investment in bolstering natural gas infrastructure, current markets will not be sustainable, nor increasing demands be met (ICF 47). The following sections provide overviews of five selected components of natural gas infrastructure: unconventional resource production (i.e., shale gas), processing, storage, pipeline transmission, and refueling.

\section{Shale Gas Development}

One of the most significant recent developments in U.S. natural gas production has been increased availability of "unconventional gas resources," and particularly of shale gas. New technologies and drilling techniques have emerged that are allowing extraction from formerly inaccessible sources; this, coupled with the increased estimates of resources of large shale basins, such as the Marcellus in Pennsylvania, New York, Ohio, and West Virginia, have 
sharpened interest in natural gas (Connors et al. [MIT], 63; ICF, 10). The co-occurrence of advances in drilling (e.g., horizontal and hydrofractuing/hydraulic fracturing) and better understanding of available unconventional gas resources have increased supply estimates by 45\%in the last decade (Werpy et al. 10). While environmental concerns about the possible effects of such drilling are substantial, particularly in water management and containment/disposal of fluids used in the fracturing process, these concerns have been characterized as "manageable but challenging" (Connors et al. [MIT], xiii).

\section{Processing}

Once removed from production sites, natural gas must undergo processing to create "pipeline quality gas," which accounts for factors such as BTU range, contaminants, and presence of liquid water (Connors et al. [MIT], 60). Processing is another facet of natural gas infrastructure affected by regional shifts in production to areas with unconventional resources, with an estimated need for increased processing capacity requiring \$11-22 billion in investment (ICF, 78-79).

\section{Storage}

Storage creates a significant challenge in natural gas infrastructure. The requirements for storage of natural gas are much greater than petroleum (Werpy et.al, 2). Natural gas is held in underground facilities, which authorities note may be inadequate to meet current and predicted increases in demand. For example, the Federal Energy Regulatory Commission noted in 2006 that while demand for natural gas had increased by $24 \%$ in the two decades preceding their study, storage capacity in the same period had increased by only $1.4 \%$ (Connors et al. [MIT], 61). In 2009, ICF International (a professional services and technology firm) delivered to 
the Interstate Natural Gas Association of America a report of storage and pipeline infrastructure projections through 2030. This report noted that, to support projected market growth of natural gas in electricity and industrial sectors, as well as to connect Arctic sources of natural gas to distributors and consumers would require approximately 370 to 600 billion cubic feet of additional storage capacity (ICF, 3). Estimated costs of such expansion are between $\$ 2,000,000,000-5,000,000,000($ ICF, 3).

\section{Pipeline Transmission}

Several challenges must be met in current pipeline systems to support increased use of natural gas. More pipelines are needed, in new places (as production regions shift), with increased volume capacity and careful attention to safety issues.

The first issue is a relative lack of pipelines. ICF notes that, "To accommodate the changes in natural gas supply and demand, the U.S. can Canada will need 28,900 to 61,900 miles of additional gas pipeline by 2030 . This will require an investment of $\$ 108$ to $\$ 163$ billion in pipeline assets" (3). Construction of new pipelines is a relatively time-consuming process, with projects taking an average of three years to complete (from project conception to service) (http://205.254.135.24/pub/oil gas/natural gas/analysis publications/ngpipeline/develop.htm l). Once need for a pipeline has been demonstrated, development options (e.g., conversion of an existing oil pipeline vs. new construction) must be considered, construction approval obtained (including financing and interaction with appropriate regulatory agencies), a review and approval process undertaken (e.g., by the Federal Energy Regulatory Commission or through the National Environmental Policy Act); construction completed (with occasional time delays due to local permitting requirements), and commissioning and testing finalized 
(http://205.254.135.24/pub/oil gas/natural gas/analysis publications/ngpipeline/develop.htm

l). Thus, increasing the pipeline system is a complicated process that must be planned well in advance.

The changing nature of regional production of natural gas also must be addressed in the pipeline system. Not only must overall pipeline system be augmented, the regions with the largest projected production growth (i.e., those with large unconventional resources) lack a solid baseline of infrastructure (Connors et al. [MIT], xv). For example, less than half of natural gas wells in Pennsylvania, a significant component of the Marcellus basin, have pipeline access (Connors et al. [MIT], 64). Additionally, the populations of those many of these regions lack familiarity with natural gas and/or oil production, leading to possible resistance to development or expansion projects. For instance, environmental concerns and subsequent protests (e.g., socalled "not in my backyard" movements) can lead to conflicts in infrastructure programs (Connors et al. [MIT], 64).

Attention to pipeline safety is also essential. The Pipeline Safety Improvement Act of 2002 imposed safety and integrity regulations on natural gas pipelines including, among other stipulations, inspections on a seven-year cycle; increased penalties for standards violations; collaborative programs for research, development, demonstration, and standardization; and whistle-blower protection for employees (ICF 68; http://www.eia.gov/oil gas/natural gas/analysis publications/ngmajorleg/pubsafety.html). While recent studies demonstrated impressive results in pipeline integrity, these issues remain pertinent, particularly in light of necessary increases in the system (ICF, 68). 


\section{Refueling}

Increased adoption of natural gas vehicles is largely contingent on readily accessible refueling infrastructure. Kragha (2010) notes that several factors create a chain reaction: tanks in natural gas vehicle have less capacity than petroleum counterparts due to higher storage density of natural gas, smaller tank capacity leads to shorter driving ranges, and diminished driving ranges necessitate more refueling stations. However, natural gas distributors are disinclined to undertake large-scale station construction initiatives when relatively fee natural gas vehicles are in use, while consumers are unwilling to purchase vehicles which they may have trouble refueling. In addition to concerns about a lack of patrons at refueling stations, natural gas distributors face large outlay costs (approximately $\$ 250,000-500,000$ for initial equipment installation), as compared to petroleum stations (Kragha 32). This cluster of concerns results in a refueling infrastructure insufficient to accommodate large-scale transportation fuel adoption - in 2010, there were less than 800 natural gas stations in the U.S., as compared to approximately 164,000 petroleum stations (Kragha 31), although others suggested there are nearly twice that many refueling stations (http://www.naturalgas.org/overview/uses transportation.asp). Kragha notes that successful adoption of alternative fuels would require a refueling infrastructure with a minimum ratio of $10-20 \%$ of alternative refueling options to conventional stations - the numbers noted above indicate a shortfall of at least 15,000 stations (32).

Attempts to address the lack of refueling infrastructure, while inventive, have been largely unsuccessful in affecting large-scale natural gas transportation adoption for individual motorists. For example, Honda, which manufactures the only CNG passenger car readily 
available in U.S. markets (the Honda Civic GX), has had mixed results in marketing "Phill," a home-fueling appliance. The system, which connects to existing energy supplies at the user's home, costs between $\$ 4,000-6,000$, including installation, a significant investment for consumers. Initial efforts through defunct manufacturer FuelMaker resulted in approximately 400 sales (Werpy et al., 7). In March 2011, Honda announced renewed production of Phill, now through Fuel Systems Solutions and a number of subsidiaries. However, partners in the initiative note that markets are still very constrained - so much so that promotion and advertising of the system has been largely absent. Technical drawbacks of Phill, including a refuel time of nearly 24 hours, also likely contribute to limited consumer interest (http://www.autoobserver.com/2011/03/brc-fuelmaker-again-selling-phill-home-cng-fuelstation.html).

\section{Summary and Conclusion}

The U.S. Energy Information Administration (EIA) regularly publishes the Annual Energy Outlook (AEO), most recently updated through 2011 (AEO2011). At law, EIA forecasts, including data and analyses, are independent of approval by any other employee of the U.S. government. Thus, while its analyses are not without variance and on occasion debate, they are considered authoritative.

AEO2011 is relatively bullish on the supply for natural gas through 2035 . While most sources of natural gas are expected to decline or remain constant at best, the EIA forecasts a rapid rise in shale gas, a trend firmly established in 2006. By 2035, shale gas will constitute 47 
percent of U.S. domestic production, nearly triple its proportion today

(http://www.eia.gov/forecasts/aeo/MT naturalgas.cfm).

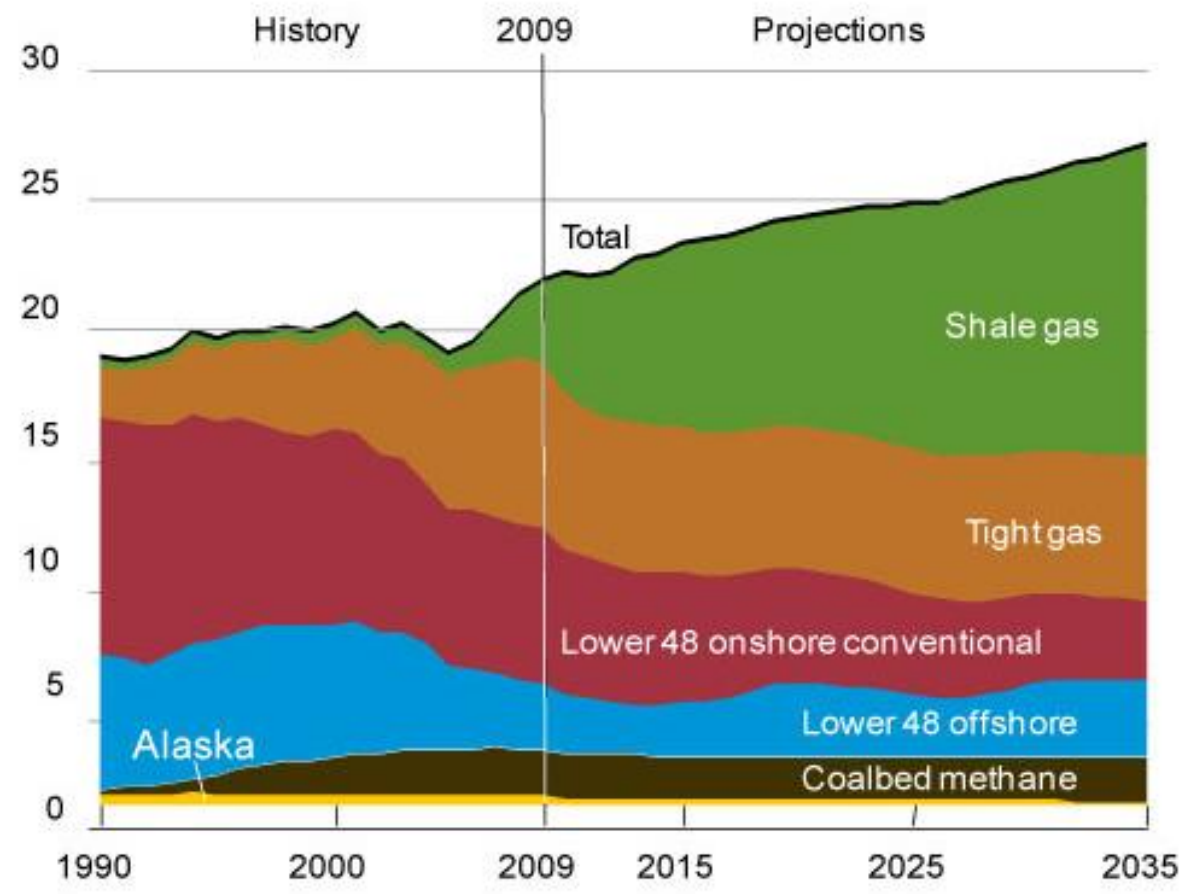

Shale gas plays-enabled by horizontal drilling and hydraulic fracturing-embodies both

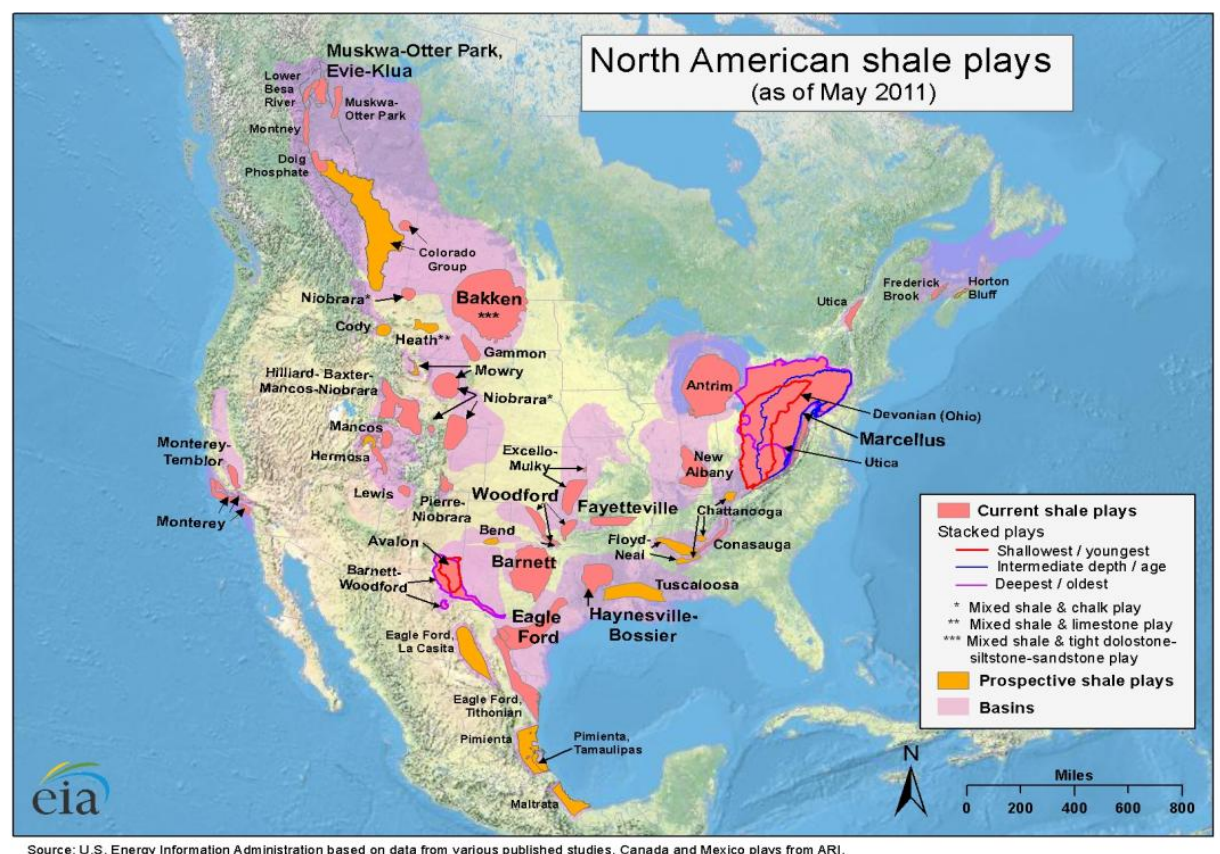

the prospect and

problem of natural

gas. Their scale and

geographic scope are

unprecedented

(http://www.eia.gov/

pub/oil gas/natural g

as/analysis publicatio

ns/maps/maps.htm). 
Experience and technological advancement continue to push estimates for technically and economically recoverable shale gas higher. Current infrastructure, already limited--only a portion of Marcellus has even been production tested-will become even less adequate to support future supply possibilities. Without adequate supply to market, demand for natural gas vehicles likewise will fail to materialize. Widespread adoption of natural gas as a transportation fuel at present is a classic causality dilemma. 


\section{References}

Conners, Stephen R., et al., 2010, The Future of Natural Gas, An Interdisciplinary MIT Study (Interim Report), MIT Energy Institute, Cambridge, MA, available at: http://web.mit.edu/mitei/research/studies/naturalgas.html.

ICF International, October 2009, Natural Gas Pipeline and Storage Infrastructure Projections through 2030, The INGAA Foundation, Inc., Washington, D.C., available at: http://www.ingaa.org/File.aspx?id=10509.

Jibson, Ron, April 2010, Full Speed Ahead, American Gas, available at:

http://www.questargas.com/FuelingSystems/NGV/RonJibsonsNGVstoryinAmericanGasMagazin e.pdf.

Kragha, Ogehenerume Christopher (MIT Master's Thesis), June 2010, Economic Implications of NGV Technology in U.S. Private Automobile Transportation, available on line at: http://globalchange.mit.edu/files/document/Kragha MS 2010.pdf

Werpy, M.R., et al., August 2010, Natural Gas Vehicles: Status, Barriers, and Opportunities, Report ANL/ESD/10-4, Energy Systems Division, Argonne National Laboratory, Argonne, IL, available on line at: http://www.transportation.anl.gov/pdfs/AF/645.PDF

U.S. Department of Energy, Energy Information Administration (EIA), 2011, Annual Energy Otlook 2011, Washington, D.C., available on line at: http://www.eia.gov/forecasts/aeo/. 